\title{
Equity Sales in Belgian Corporate Groups: Expropriation of Minority Shareholders? ${ }^{(*)}$
}

\author{
An BUYSSCHAERT \\ Free University of Brussels (VUB) \\ E-mail: An.Buysschaert@,vub.ac.be \\ Marc DELOOF \\ University of Antwerp \\ E-mail: Marc.Deloof@ua.ac.be
}

Marc JEGERS

Free University of Brussels (VUB)

E-mail: Marc.Jegers@vub.ac.be

${ }^{*}$ We thank Ariane Chapelle, Ilse Verschueren and Wim Voordeckers for valuable comments and suggestions. Financial support by the Fund for Scientific Research - Flanders (Belgium) is gratefully acknowledged. 


\title{
Equity Sales in Belgian Corporate Groups: Expropriation of Minority
}

\author{
Shareholders?
}

\begin{abstract}
In Belgian corporate groups, complex pyramidal structures and interlocking ownership lead to separation of ownership and control. This may generate incentives for the controlling shareholder to divert resources within the group through intragroup equity sales. This in turn could lead to significant private benefits at the expense of the minority shareholders. We test this hypothesis by investigating the stock price reaction to the announcement of equity sales in Belgian groups. Our results suggest that intragroup equity sales create value for minority shareholders. Equity sales between group members and non-group members do not seem to affect the value for minority shareholders in Belgian groups.
\end{abstract}

JEL classification: G14, G32, and G34 


\section{Introduction}

Gaining insight in the financial mechanisms in Continental European corporate groups is difficult and research on this issue is relatively scarce. The literature primarily focuses on American conglomerates and multidivisional structures, which are very different from European groups. American conglomerates are tightly structured, whereas Continental European groups are often loose organizations with an ill-defined global policy. In Belgium, these groups are characterized by complex pyramidal structures, interlocking ownership and voting pacts. These structures allow the ultimate owner to maintain control over a large group of companies through cascades of holding companies, while owning only a fraction of their cash flow rights. ${ }^{1}$ This separation of ownership and control generates strong incentives for the controlling shareholder to divert resources between companies in the group.

The shares of most listed Belgian holding companies, which function as intermediates in ownership structures, trade at a significant discount relative to their net asset value. If the price at which these shares are traded on the stock market reflects the value for minority shareholders, this suggests that there are significant private benefits for the controlling shareholder(s), at the expense of the minority shareholders. A minority shareholder who holds a stake of $\mathrm{x} \%$ in the company's equity does not receive $\mathrm{x} \%$ of total company value, but only $\mathrm{x} \%$ of [total company value - private benefits extractable by the controlling shareholder(s)]. The diversion of resources between companies at the

\footnotetext{
1 See Renneboog (1997) and Van Hulle (1998) for a more extended analysis of Belgian holding structures; Banerjee, Leleux and Vermaelen (1997) for an interesting analysis of French holding structures and Bigelli and Mengoli (1999) for Italian ones, which are both very comparable to Belgian holding structures. The Italian equity market is also similar to the Belgian equity market: few companies are quoted, concentration of ownership is high, and pyramidal ownership structures with holding companies as intermediate investment vehicles are common (Bianchi, Bianco and Enriques, 2000).
} 
expense of minority shareholders has been labeled tunneling (La Porta et al., 2000). It can take many forms, such as selling of inputs or purchase of outputs at non-market prices, or high or low interest rate loans. In pyramidal structures wealth may be transferred from the companies located at the lower levels of the group towards companies at the upper levels, where the ownership of the controlling shareholders, in terms of cash flow rights, is less diluted.

In this paper, we first investigate the stock market price reaction to the announcement of equity sales between companies that belong to the same Belgian group (at least one of them being a holding company). While there can be several reasons for equity sales, such as a change in the control structure, transparency reasons, etc., we focus on wealth transfers. If these equity sales lead to a transfer of wealth from companies at the lower levels of the group towards companies at the upper levels of the group, we expect a negative price reaction for the company at a lower level. Moreover, we expect a positive price reaction for the company at the upper level if some of the wealth transferred to this company is not expropriated as private benefits, but is available to all shareholders of that company. The sample we use to test this hypothesis consists of all 15 significant intragroup equity sales that were announced in the leading Belgian financial newspaper 'De Financieel Economische Tijd' in the 1996-1999 period. The results show a significant positive price reaction to the announcement of equity sales within Belgian groups for both upper and lower level companies. The hypothesis that these sales are priced so as to transfer wealth to the upper level, at the expense of the minority shareholders of the lower level company, is therefore not confirmed. Instead, our results suggest that the buying/selling of equity stakes within Belgian corporate groups creates value for the minority shareholders of both companies. 
Second, we investigate the share price reaction when a Belgian holding company announces either the sale of an equity stake to a non-group buyer, or the purchase from a non-group seller of an additional equity stake in a company in which the holding company already has a stake. If these transactions are part of a strategy that creates value for minority shareholders, we expect a positive price reaction of the holding's shares. On the other hand, if these transactions destroy value for minority shareholders, a negative price reaction is to be expected. The sample we use to test this hypothesis consists of 26 equity sales to or from a non-group partner in the 1996-1999 period. We find no evidence that the sale of an equity stake to a non-group buyer or the purchase of an additional equity stake from a non-group seller significantly affects the value of minority shareholders of Belgian holding companies.

The remainder of the paper proceeds as follows. Section 2 reviews the features of Belgian corporate groups and holding companies. In Section 3, we outline the research questions. We discuss the sample and the research methodology in Section 4. The results are presented and analyzed in Section 5. We conclude in Section 6.

\section{Corporate groups and holding companies in Belgium}

Banerjee, Leleux and Vermaelen (1997) define a holding company as "a professionally managed institution owning a portfolio of stocks in public and private companies with the purpose of influencing them. In realizing this objective, a holding company acts 
both as a financial intermediary and as an active shareholder."2. A corporate group or business group can be defined as a set of legally distinct companies, that are all subject to the direct or indirect control of a single leadership (an individual, a coalition of individuals, or a government body) (Bianchi, Bianco and Enriques, 2000).

In Belgium, there were 144 companies listed on the Brussels Stock Exchange (BXS) at the end of 1999. While companies on the BXS are of various sizes and may belong to any sector of the economy, holding companies play a major role: they accounted for $32 \%$ of market capitalization in 1998. In 1999 their market capitalization fell back to $19 \%$ (Report of the market authority Brussels Stock Exchange, 2000). The BXS itself is a small stock market, which has experienced a strong growth in the second half of the 1990s: the market capitalization, which was $38 \%$ of Belgian GDP in 1995, had grown to $80 \%$ of GDP in 1999 . This market capitalization is highly concentrated among a few large companies. In 1996 the Top 10 companies accounted for 50\% of total market capitalization, while the Top 50 companies represented $95 \%$ of market capitalization. In 1999, the companies of the 'BEL20', a stock market index that includes the 20 largest listed Belgian companies, accounted for $78 \%$ of market capitalization. The analyses of Becht and Chapelle (1997) and Becht, Chapelle and Renneboog (2000) reveal that control is also highly concentrated: in 1995, the largest direct shareholding was on average $45 \%$, while the second largest shareholder held on average $11 \%$. For most Belgian companies, equity stakes are concentrated into powerful control blocks through group structures and voting pacts. In December 1995, 135 companies out of 140 received the notification that at least one shareholder held a stake or block of $5 \%$ or

\footnotetext{
${ }^{2}$ Other authors present similar definitions. They all come down to these same basic elements of creating value and controlling through buying, holding and selling equity stakes in other companies (see for
} 
more in the company. In total, 750 stakes were held by 562 direct shareholders. These stakes corresponded to 489 group blocks held by 328 business groups. Voting blocks between these shareholders and/or business groups resulted in 269 voting blocks controlled by 195 different voting pacts (Becht and Chapelle, 1997).

The complex pyramidal structures, interlocking ownership and voting pacts, that are characteristic for Belgian corporate groups, allow the ultimate owner to maintain control over a large group of companies, while owning only a fraction of their shares. A good example of such a group is the Belgian group around businessman Albert Frère.

*** Figure 1 about here $* * *$

Figure 1 represents a simplified version of the shareholder structure of this group in 1998. The group is dominated by the Frère-Bourgeois company, which is a non-listed entity directly controlled by Frère. A chain of intermediate holding companies allows him to control a vast industrial empire with relatively small cash flow stakes.

The structure of pyramidal business groups such as the Frère empire involves potential agency problems between controlling and minority shareholders. The controlling shareholders typically have a power over firms that significantly exceeds their cash flow rights. In this regard, La Porta et al. (1999) conclude “... the central agency problem in large corporations around the world is that of restricting expropriation of minority 
shareholders by controlling shareholders ...”. ${ }^{3}$ This separation of ownership and control in pyramidal groups, indeed, generates strong incentives for the controlling shareholder to divert resources between companies in the group for his benefit, at the expense of minority shareholders, so called tunneling. Bertrand, Mehta, and Mullainathan (2000) find evidence on tunneling in Indian business groups. Their results show that the diversion of resources follows the lines of ownership, flowing from firms near the bottom of the pyramid to firms near the top of the pyramid. Furthermore, they are able to discern that much of this diversion occurred on non-operating components of profits. Similar results are found by Bigelli and Mengoli (1999) for Italy. They hypothesize that the high separation of ownership and control achieved in Italian listed companies through the use of non-voting shares and stock pyramiding, may favor acquisitions made to increase the private benefits to the controlling shareholders rather than total shareholders' wealth. Their research reveals that for acquisitions made within a pyramidal group the price is set so as to transfer wealth towards the companies located at the upper levels of the pyramidal chain, where the ownership of the majority shareholders is less diluted. Bae, Kang and Kim (2000) use Korean mergers to investigate the nature of business groups in emerging markets and examine whether Korean business groups, Chaebols, add value to their member firms, or provide the controlling shareholders with an opportunity for wealth transfer. Their results also support the tunneling view that firms belonging to business groups pay less attention to the maximization of individual firm value and make takeover decisions that are beneficial to controlling shareholders only.

\footnotetext{
${ }^{3}$ This type of agency problem between controlling and minority shareholders can be particularly serious when there are few mechanisms to protect minority investors and to control the discretionary power of
} 
The shares of most listed Belgian holding companies trade on the stock market at a significant discount compared to their estimated net asset value. Early research by Siaens and Walravens (1993) revealed that this discount, which can be defined as the percentage difference between the net asset value per share and the stock market share price at a fixed date, varies between $10 \%$ and $50 \%$. Figure 2 and Figure 3 show the evolution of the discount of the share price to the net asset value of Groep Brussel Lambert (GBL), a holding company that belongs to the Albert Frère empire (see Figure 1). GBL publishes its estimated net asset value weekly on its website and in the Saturday edition of the two Belgian financial newspapers. The reported net asset value of the GBL share provides a snapshot of the company at a given day. This value is obtained by valuing the portfolio of GBL shareholdings at its market value, and adding the cash and cash equivalents of the group (taking debts and provisions into account). Figure 2 presents weekly data on the share, the net asset value per share and the discount, over the 1999-2000 period. In this period the discount varied between $30 \%$ and 55\%. Figure 3 shows the yearly evolution over the 1991-2000 period. It is remarkable that the average discount increased from $13.5 \%$ in 1991 to $39 \%$ in 2000 (Annual reports of Groep Brussel Lambert).

\footnotetext{
$* * *$ Figure 2 about here $* * *$

*** Figure 3 about here $* * *$
}

If the stock market price of Belgian holding companies reflects the value for minority shareholders, the discount at which Belgian holding companies trade suggests that there 
are significant private benefits for controlling shareholders, at the expense of minority shareholders. The discount on net asset value for these holding companies may then be the market's estimation of wealth transfers through tunneling.

\section{Research objectives and hypotheses}

Our research question is whether listed holding companies in Belgian corporate groups create private benefits for the controlling shareholders at the expense of the minority shareholders, through the sale or the purchase of equity stakes. We restrict this study to equity sales involving holding companies, because it is precisely the goal of holding companies to create value through buying, holding, and selling equity stakes in other companies.

First, we investigate equity sales within corporate groups in which a holding company is involved. We test whether in Belgian pyramidal groups resources are transferred as a means of expropriating wealth from companies at the lower levels of the group to companies at the upper levels of the group. The ownership of the controlling shareholder is more diluted at the bottom of a pyramidal group than at the top of the group. It can therefore be expected that when a company at the top of the pyramid buys an equity stake in another company from a company at the bottom, the price tends to be set at a discount to its fair value. On the other hand, if a company at the top of the pyramid sells an equity stake in another company to a company at the bottom, we expect the price paid to be higher than the fair value. In our research, we do not only consider related companies where one has direct control over the other, but all companies that are located upstream or downstream with respect to each other in a 
pyramidal group. If the purpose of an intragroup equity sale is to transfer wealth from the company at the lower level to the company at a higher level of the group, this announcement should lead to a positive price reaction for the company located at the upper level and a negative price reaction for the lower level company.

Second, we investigate equity sales between a holding company that is part of a group, and a non-group buyer or seller. We study the price reaction of the holding company when it announces the sale of an equity stake in a lower level company to a non-group buyer, or when it announces the purchase of an additional equity stake in a lower level company from a non-group seller. If these transactions create value for minority shareholders, we expect a positive price reaction. If the transaction destroys value for minority shareholders, a negative price reaction is expected.

\section{Database and methodology}

\subsection{The database}

In order to obtain the relevant events, we first need a clear definition of a holding company. Following previous studies on Belgian holding companies, we use the classification of the Belgian Stock Exchange (BXS,) which excludes pure financial holding companies. The BXS defines holding companies as "those companies which purpose is to invest in other quoted companies, except financial institutions". We also exclude investment companies, which are organizations that take a pool of investors' money and invest it in securities according to a stated set of objectives, and partially government-owned holding companies. This results in the identification of 26 listed holding companies in the 1996-1999 period. 
For each holding company, we include all the events that fulfilled the following criteria:

1. The announcement date is clearly mentioned in the leading Belgian (Flemish) financial newspaper "De Financieel Economische Tijd". We define the announcement date as the date where the purchase/sale is officially reported by the company for the first time ${ }^{4}$.

2. Stock prices and returns, adjusted for dividends, are available from 133 trading days before the announcement date until 30 days after.

3. The equity stake that is traded must be at least $5 \%$ of total equity (measured in number of shares).

To test the first hypothesis, we consider all equity sales where the buyer and the seller belong to the same group and at least one of them is a holding company. The corporate groups were identified by consulting the annual reports of the holding companies, which have to be filed with the National Bank of Belgium. In this way we obtain 15 transactions, 7 of which concern the price reaction of the shares of an upper level company ( 3 purchases and 4 sales). The remaining 8 concern the price reaction of a lower level company (4 purchases and 4 sales).

To test the second hypothesis, we include all the events where a holding company that belongs to a group sells an equity stake in another company to a non-group buyer, or where a holding company buys an additional equity stake in a lower level company from a non-group seller. This sample consists of 26 transactions. All the events are described in Table 1 (first hypothesis) and Table 2 (second hypothesis).

\footnotetext{
${ }^{4}$ When the announcement date was not a trading day, we consider the next trading day as "day 0".
} 


\section{*** Table 1 about here $* * *$ \\ *** Table 2 about here ***}

Both tables contain the positions of the companies with respect to each other in the group, the event date, the size of the equity stakes, and the type of transaction. Table 1 is divided in Panel A and Panel B. Panel A reports the events for which the price reactions of the company located at the upper level of the group will be analyzed, while Panel B contains the events for which the price reactions of the company located at the lower level will be studied ${ }^{5}$.

\subsection{Event study analysis}

We use standard event study methodology to test the hypotheses. Abnormal returns, $A R_{i t}$, are defined by the market-adjusted model as well as by the market model adjusted for the thin trading bias (Dimson, 1979). The Dimson beta was calculated by the use of three lagged market returns and one leading market return ${ }^{6}$. For the market return we use the "Belgian All Shares Return Index", which is a value weighted return index. The

\footnotetext{
${ }^{5}$ Panel A and B are not symmetric, because some group members may not be listed on the Belgian Stock Exchange. If these companies are not listed, no stock price data are available.

${ }^{6}$ Similar results were found using the standard market model. This could be expected since Dyckman, Philbrick and Stephan (1984) and Brown and Warner (1985) find that using Dimson Estimates results in reduced biases in the OLS estimates of beta but does not result in an improvement in either the specification power of the event study tests (i.e. thin trading does affect both the alpha and the beta estimate, leaving the residual almost unaffected)
} 
parameters of the market model are estimated in the pre-event window period from trading days -130 until -31 . For the event window, both a period of 60 days a period of 10 days around the event date are considered since we do not know whether information on new sales or purchases of equity stakes gradually enters the market through rumors anticipating the official announcement.

The individual security $i$ 's abnormal returns experienced on day $t$ of the event window, $A R_{i t}$, are defined as the difference between the actual returns $R_{i t}$ and the expected returns:

$$
A R_{i t}=R_{i t}-R_{m t} \quad \text { for the market-adjusted model }
$$

$$
A R_{i t}=R_{i t}-\alpha_{i}-\sum_{k=-3}^{k=+1} \beta_{i k} R_{m, t+k}
$$

for the Dimson adjusted market model (2)

where: $R_{m t}$ is the return of the Belgian All Shares Return Index on day $t$ $\alpha_{i}$ and $\beta_{i k}$ (Dimson betas with $k \in[-3,+1]$ ) are OLS estimators for stock $I$

The null hypothesis to be tested is that the average abnormal return on day $t, A A R_{t}$, is equal to zero, and thus that the event on average does not affect returns to shareholders. To perform the test we use the standardized t-test (two-sided), described in Brown and Warner (1985):

$$
\text { test statistic }=\frac{A A R_{t}}{\sigma\left(A A R_{t}\right)} \quad \text { for the market-adjusted model and }
$$


for the Dimson adjusted model

where

$$
\begin{aligned}
& A A R_{t}=\frac{1}{N} \sum_{i=1}^{N} A R_{i t} \\
& \sigma\left(A A R_{t}\right)=\sqrt{\sum_{t=-130}^{-31}\left(A A R_{t}-\overline{A A R}\right)^{2} /(100-1)} \\
& \overline{A A R}=\frac{1}{100} \sum_{t=-130}^{-31} A A R_{t}
\end{aligned}
$$

and where $N$ is the number of events used to test the specific hypothesis.

Further, we also test the significance of the cumulative average abnormal return over the 60-day and 10-day estimation periods, $C A A R_{-30,+30}$ and $C A A R_{-10,+10}$, under the null hypothesis that the $C A A R_{-v,+v}$ is zero. Therefore, again we perform a standardized t-test (two-sided):

$$
\text { test statistic }=\frac{C A A R_{-v,+v}}{\sigma\left(C A A R_{-v,+v}\right)} \quad \text { for the market-adjusted model and }
$$

for the Dimson adjusted model

where 


$$
\begin{aligned}
& C A A R_{-v,+v}=\sum_{t=-v}^{+v} A A R_{t} \\
& \sigma\left(C A A R_{-v,+v}\right)=\sqrt{(2|v|+1)} \times \sigma\left(A A R_{t}\right)
\end{aligned}
$$

and where $[-v,+v]$ is the event window, $[-30,+30]$ and $[-5,+5]$ respectively.

If the standardized excess returns are independent and identically distributed and have finite variance, the central limit theorem applies and thus the derived test statistic will asymptotically be standard normally distributed under the null hypothesis. We did not adjust for autocorrelation, non-synchronous trading and clustering since Brown and Warner (1985) demonstrate that simple tests based on the OLS method are fairly specified without such adjustments.

Some properties of infrequent traded securities are likely to differ from those of more heavily traded securities. This has implications for event study methods? Thinly traded stocks are more likely to be characterized by numerous zero and large non-zero returns, resulting in non-normal return distributions. That is why we also use the nonparametric Corrado rank test (Corrado, 1989). This test does not depend on the assumption of normality. Compared with its parametric counterparts and with standard nonparametric tests, this rank test offers improved specification under the null hypothesis and is more powerful under the alternative hypothesis of abnormal security-price performance. Further, the rank test is shown to be resistant to misspecification caused by an eventdate excess-returns variance increase (Corrado, 1989). 
Implementing this procedure involves first transforming each security's time series of abnormal returns into a series consisting of their respective ranks. The ranking procedure transforms the distribution of security abnormal returns into a uniform distribution across the possible rank values regardless of any asymmetry in the original distribution (i.e. departures from normality like right skewness and fat tails).

Let $K_{i t}$ denotes the rank of abnormal return $A R_{i t}$ (for both the market-adjusted and the Dimson adjusted model) in security $i$ 's time series of 161 excess returns:

$$
K_{i t}=\operatorname{rank}\left(A R_{i t}\right) \quad t=-130, \ldots,+30
$$

Where $A R_{i t} \geq A R_{i j}$ implies $K_{i t} \geq K_{i j}$ and $161 \geq K_{i t} \geq 1$. Thus, rank 1 signifies the smallest abnormal return; rank 161, the largest. By construction, the average rank is one-half plus half the number of observed returns, or 81 . The rank statistic substitutes $\left(K_{i t}-81\right)$ for the abnormal return $A R_{i t}$, yielding this day 0 test statistic:

$$
\text { test statistic }=\frac{\frac{1}{N} \sum_{i=1}^{N}\left(K_{i 0}-81\right)}{\sigma(K)}
$$

where

$$
\sigma(K)=\sqrt{\frac{1}{161} \sum_{t=-130}^{+30}\left(\frac{1}{N} \sum_{i=1}^{N}\left(K_{i t}-81\right)\right)^{2}}
$$


Corrado (1989) describes the rank test for a one-day event window, but actual event studies often test windows of two or more days. The ranks of the abnormal returns of different days are dependent by construction. However, the effect of ignoring the dependence may be negligible for event windows of a few days. Cowan (1992) extends the rank test to windows of 2 to 11 days by assuming that the daily return ranks within the window are independent. The rank test procedure treats the 150 -day estimation period and the 11-day event period as a single time series, and assigns a rank to each daily return for each company. Following the previous notation, $K_{i t}$ represents the abnormal return $A R_{i t}$ in the time series of 161 daily abnormal returns of stock $i$. It is worth noting that we restrict this test to 10 days around day 0 (and do not execute it for the 60 day period) as no studies were found where a longer period is successfully used. The rank test statistic for the event window composed of days $D_{1}$ through $D_{d}$ then is:

$$
\text { test statistic }=\sqrt{d} \frac{\overline{K_{D}}-81}{\sqrt{\sum_{t=1}^{161}\left(\overline{K_{t}}-81\right)^{2} / 161}}
$$

where $\overline{K_{D}}$ is the average rank across the $n$ stocks and $d$-days of the event window $(1 \leq$ $d \leq 11)$

$\overline{K_{t}}$ is the average rank across $n$ stocks on day $t$ of the 161 day combined estimation and event period.

The null hypothesis to be tested in this nonparametric test is that the average rank over the event window $[-5,+5]$, i.e. $\overline{K_{11}}$, is equal to 81 . 


\section{Empirical results}

The results of both the parametric and nonparametric tests are summarized in Table $3^{7}$. Figure 4 shows the average cumulative abnormal return of companies at the upper level over the 60 days period around the announcement date of an intragroup equity sale. The CAAR $_{-30,+30}$ based on the market-adjusted model is $+2.1 \%$, while the CAAR ${ }_{-30,+30}$, based on the (Dimson corrected) market model, is $+5.4 \%$ (see Table 3 ). The difference between both CAAR variables is a consequence of the low betas of the companies in our sample. A t-test indicates that neither the 60-days CAAR based on the marketadjusted model nor the 60-days CAAR based on the market model is statistically different from zero. These results are similar to the CAARs and the ranking $\overline{\mathrm{K}_{11}}$ in the 10 days around the announcement day of an intragroup equity sale (see Figure 5 and Table 3). The 10 days market model CAAR for the upper level company is $+4.4 \%$. A ttest indicates significance at the $5 \%$ level. The $\overline{\mathrm{K}_{11}}$ show a ranking of 86.6 and 88.3 for the market-adjusted and the market model respectively. Although this is well above the expected average of 81 , though none of them is significantly higher. Of course, it has to be taken into account that the sample size is very low.

The results in Table 3 indicate a significant reaction to the announcement of a purchase by the upper level company in comparison to the announcement of a sale by the company. The 60 days market model CAAR is $+8.3 \%$ for the 3 purchases by upper

\footnotetext{
${ }^{7}$ We also divided the database in 2 samples on the basis of traded equity being smaller than $20 \%$ and larger than $20 \%$. This yielded very similar results. (Tables not reported)
} 
companies, and is $-0.07 \%$ for the 4 sales by upper companies. For the 10 days period the price reaction of a purchase by the upper level company is significant at the $5 \%$ level for both models for both CAAR and $\overline{\mathrm{K}_{11}}$, while the sales price reaction is not significant. In general, the CAARs and the $\overline{\mathrm{K}_{11}}$ estimated with the market-adjusted model are lower than the ones of the market model, but the results are consistently positive.

The results indicate that equity sales within Belgian corporate groups create value for the minority shareholders of the company at an upper level: the announcement of such equity sales, purchases in particular, leads to positive abnormal returns for the upper level company.

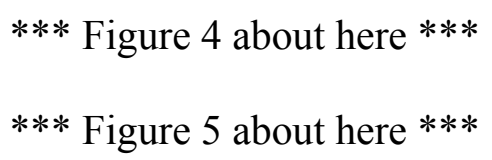

Figures 6 and 7 show the CAARs around the announcement day of an intragroup equity sale for the companies located at the lower level. If these equity sales are used to expropriate value from minority shareholders, we expect a negative price reaction for these lower level companies. However, both Figure 6 (60 days CAARs) and Figure 7 (10 days CAARs) show positive price reactions for the lower level companies. Table 3 shows that for the 8 events involving a lower level company, the 60 days market model CAAR is $+10 \%$ (significant at the $1 \%$ level), the 10 days market model CAAR is + $6.7 \%$ (significant at the $1 \%$ level) and the $\overline{\mathrm{K}_{11}}$ is 94.8 (significant at the $1 \%$ level). On the announcement date, the average abnormal return is $1.2 \%$ (significant at the $5 \%$ 
level). Again, the CAARs and $\overline{\mathrm{K}_{11}}$ based on the market-adjusted model are lower than the ones of the market model, but are also consistently positive.

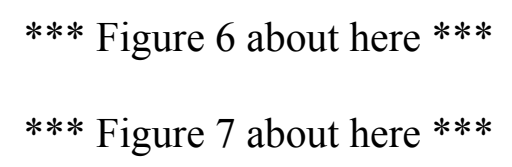

Combined, these results suggest that intragroup equity sales create value for the minority shareholders of both upper and lower level companies.

A likely explanation for these results, which contradict our hypothesis, is that the equity sales are part of a strategy of Belgian corporate groups to create a more transparent group structure. This should make the shares of group members more attractive for outside investors. Annual reports of holding companies of the Brederode group and the Frère-Bourgeois group for the time period studied explicitly mention that the group structure is being simplified through shifts in equity stakes, in order to augment transparency towards outside investors. The goal of these reorganizations is to reduce the discount of the stock market price to the net asset value of these holding companies.

Finally, we investigate the price reaction when a holding company buys or sells an equity stake in a company at a lower level to a company that does not belong to the same group. Figures 8 and 9 show the CAARs for the holding company around the announcement day. The results indicate that these transactions do not affect the value of the minority shareholders of the holding company at all. Around the announcement date, we find a 10 days market model $\overline{\mathrm{K}_{11}}$ of 79.1 , a CAAR of $-0.04 \%$, and a 60 days market model CAAR of $-0.14 \%$ for the holding companies (see Table 3 ). None of these 
results is significant. Comparable results are found when the market-adjusted model is used.

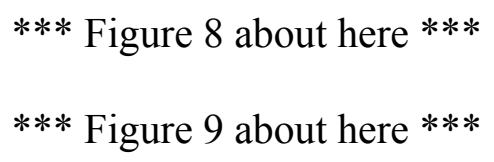

\section{Conclusion}

For a 60-day event window as well as for a 10-day event window, we find a positive price reaction to the announcement of equity sales within Belgian groups for both companies located at the upper and the lower level of the group. The hypothesis that these sales are priced so as to transfer wealth to the upper level, at the expense of the minority shareholders of the lower level company, is therefore not confirmed. Instead, our results suggest that the buying/selling of equity stakes within Belgian corporate groups creates value for the minority shareholders of both the upper and the lower level company. We find no evidence that the sale of an equity stake to a non-group buyer or the purchase of an additional equity stake from a non-group seller significantly affects the value of minority shareholders of Belgian holding companies.

Of course, it has to be taken into account that these results are based on very small samples. Nevertheless, we think that they provide a valuable insight in the mechanisms of Belgian pyramidal structures, in which holding companies play a pivotal role. It is interesting to contrast our results with the results of Bigelli and Mengoli (1999) for intragroup equity sales in Italian pyramidal groups in the 1989-1996 period. Contrary to what we find, their results are consistent with the hypothesis that intragroup sales are a means to transfer wealth from minority shareholders to the controlling shareholders at 
the upper level of the pyramid. A possible explanation for this disparity is that while the 1989-1996 equity sales in Italian groups were motivated by shareholder expropriation, the 1996-1999 equity sales in Belgian groups were a means to create a more transparent group structure. 


\section{References}

Bae, K.H., J.K. Kang and J.M. Kim, 2000, Tunneling or value addition? Evidence from mergers by Korean business groups, Working paper.

Banerjee, S., B. Leleux and T.Vermaelen, 1997, Large shareholdings and corporate control: an analysis of stake purchases by French holding companies, European Financial Management 3(1), 23-44.

Bebchuk, L., R. Kraakman and G. Triantis, 1999, Stock pyramids, cross-ownership, and the dual class equity: the creation and agency costs of separating control from cash flow rights, National Bureau of Economic Research, NBER Working paper No. 6951. Becht, M. and A. Chapelle, 1997, Ownership and control in Belgium. European Corporate Governance Network Working Paper.

Becht, M., A. Chapelle and L. Renneboog, 2000, Shareholding cascades: the separation of ownership and control in Belgium, Working paper.

Bertrand, M., P. Metha, and S. Mullainathan, 2000, Ferreting out tunneling: an application to Indian business groups, National Bureau of Economic Research, NBER Working paper No. 7952.

Bianchi, M., M. Bianco and L. Enriques, 2000, Pyramidal groups and the separation between ownership and control in Italy, Mimeo, Banca d'Italia.

Bigelli, M. and S. Mengoli, 1999, Private Benefits from New Acquisitions: Evidence from the Italian Stock Market, University of Bologna, Working Paper.

Brown, S.J. and J.B. Warner, 1985, Using daily stock returns. The case of event studies, Journal of Financial Economics 14, 3-31.

Corrado, C.J., 1989, A nonparametric test for abnormal security-price performance in event studies, Journal of Financial Economics 23, 385-395. 
Cowan, A.R., 1992, Nonparametric event study tests, Review of Quantitative Finance and Accounting 2, 343-358.

Dimson, E., 1979, Risk measurement when shares are subject to infrequent trading, Journal of Financial Economics 8, 197-226.

Dyckman, T.D., D. Philbrick and J. Stephan, 1984, A comparison of event study methodologies using daily stock returns: a simulation approach, Journal of Accounting Research 22, 1-30.

La Porta, R., F. Lopez-de-Silanes and A. Shleifer, 1999, Corporate ownership around the world, Journal of Finance 54(2), 471-518.

La Porta, R., S. Johnson, F. Lopez-de-Silans and A. Shleifer, 2000, Tunneling, American Economic Review: AEA papers and proceedings 90(2), 22-27.

Mulherin, J.H. and A.L. Boone, 2000, Comparing acquisitions and divestitures, Department of Finance, Smeal College of Business, Penn State University, Working paper

Renneboog, L., 1997, Shareholding concentration and pyramidal ownership structures in Belgium, In: Balling, Hennessy and O'Brien, Corporate Governance, Financial Markets and Global Convergence (Kluwer Academic Publishers).

Shome, D.K. and S. Singh, 1995, Firm value and external blockholdings, Financial management 24(4), 3-14.

Siaens, A. and M. Walravens, 1993, Valorisation d'un holding: le problème de la décote (Valuation of a holding company: the problem of a discount), Revue de la Banque/Bank-en Financiewezen 6, 305-313.

Strong, N., 1992, Modeling abnormal returns: a review article, Journal of Business, Finance \& Accounting 19(4), 533-553. 
Van Hulle, C., 1998, On the nature of European holding groups, International Review of Law and Economics 18(3), 255-277.

Zingales, L., 1994, The value of the voting right: a study of the Milan Stock Exchange experience, Review of Financial Studies 7(1), 125-148. 
Figure 1: Simplified version of the shareholder structure of Albert Fère's pyramidal empire in 1998.

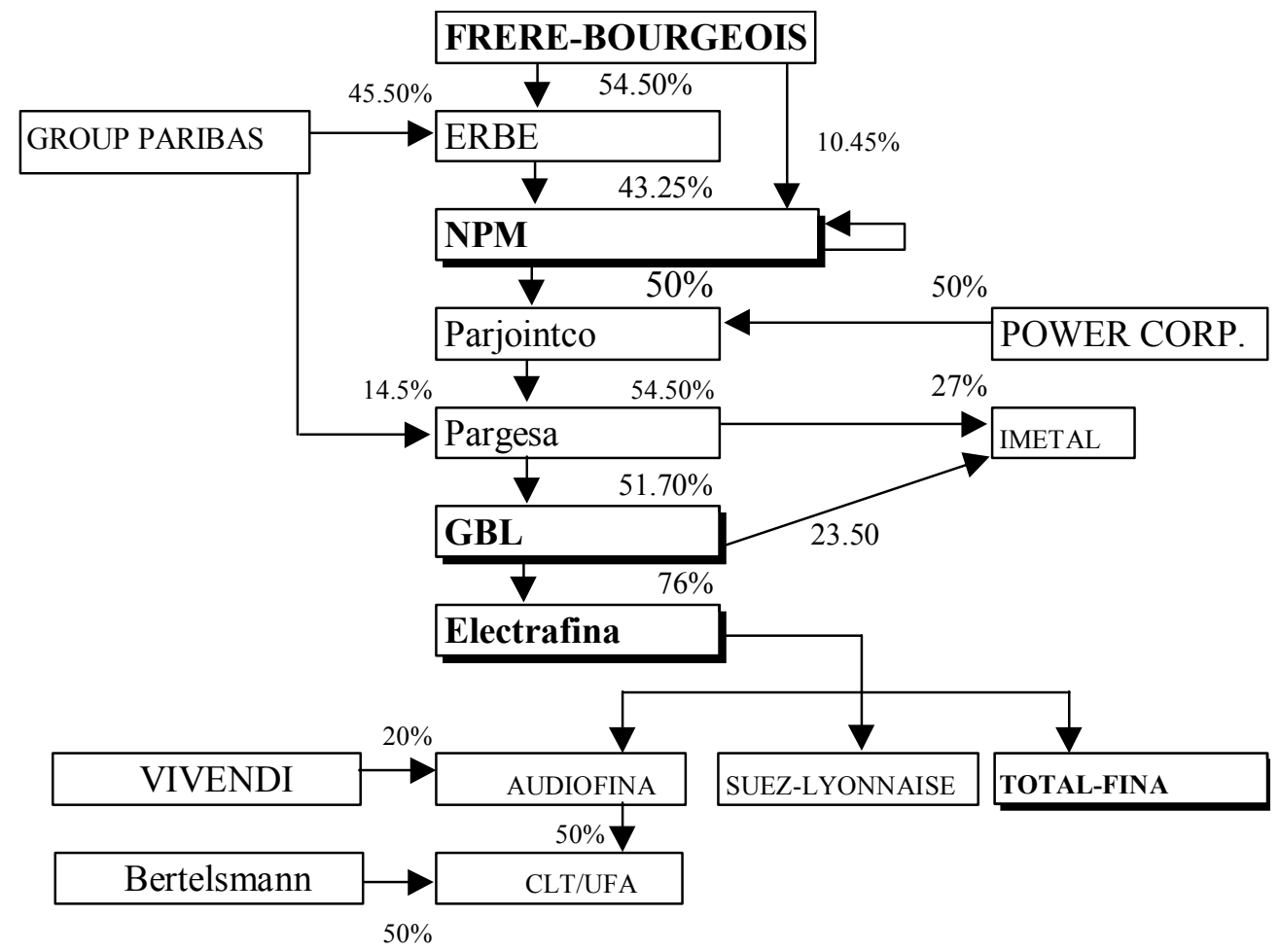

Source: Annual report Nationale Portefeuille Maatschappij 
Figure 2: Estimated net asset value per share, stock price and percentage discount: the example of Groep Brussel Lambert (1999-2000)

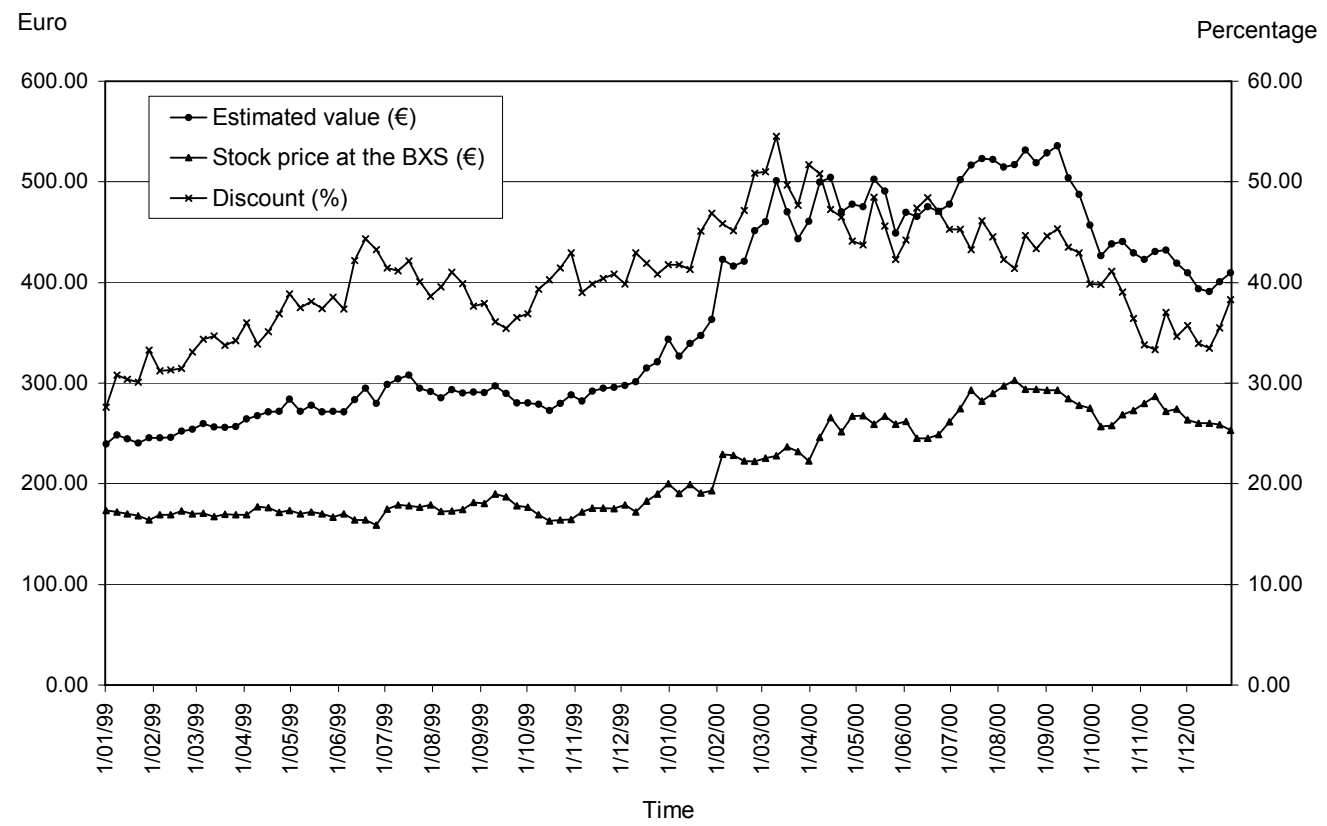

Source: Internet site of GBL: www.gbl.be (April 2001)

Figure 3: Estimated net asset value per share, stock price and percentage discount: the example of Groep Brussel Lambert (1991-2000)

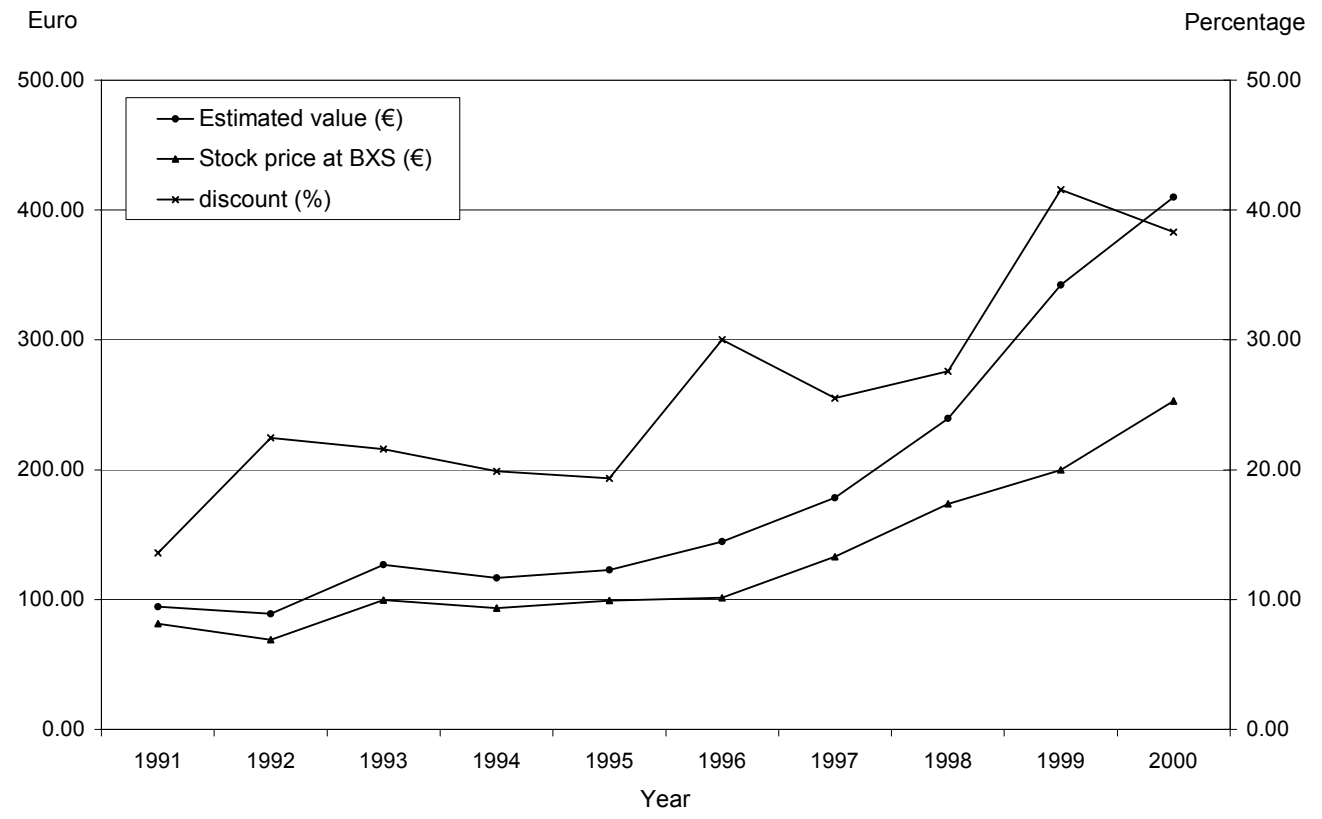

Source: Internet site of GBL: www.gbl.be (April 2001) 
Figure 4: Intragroup equity sales: cumulative average abnormal return of the upper level companies (60 days)

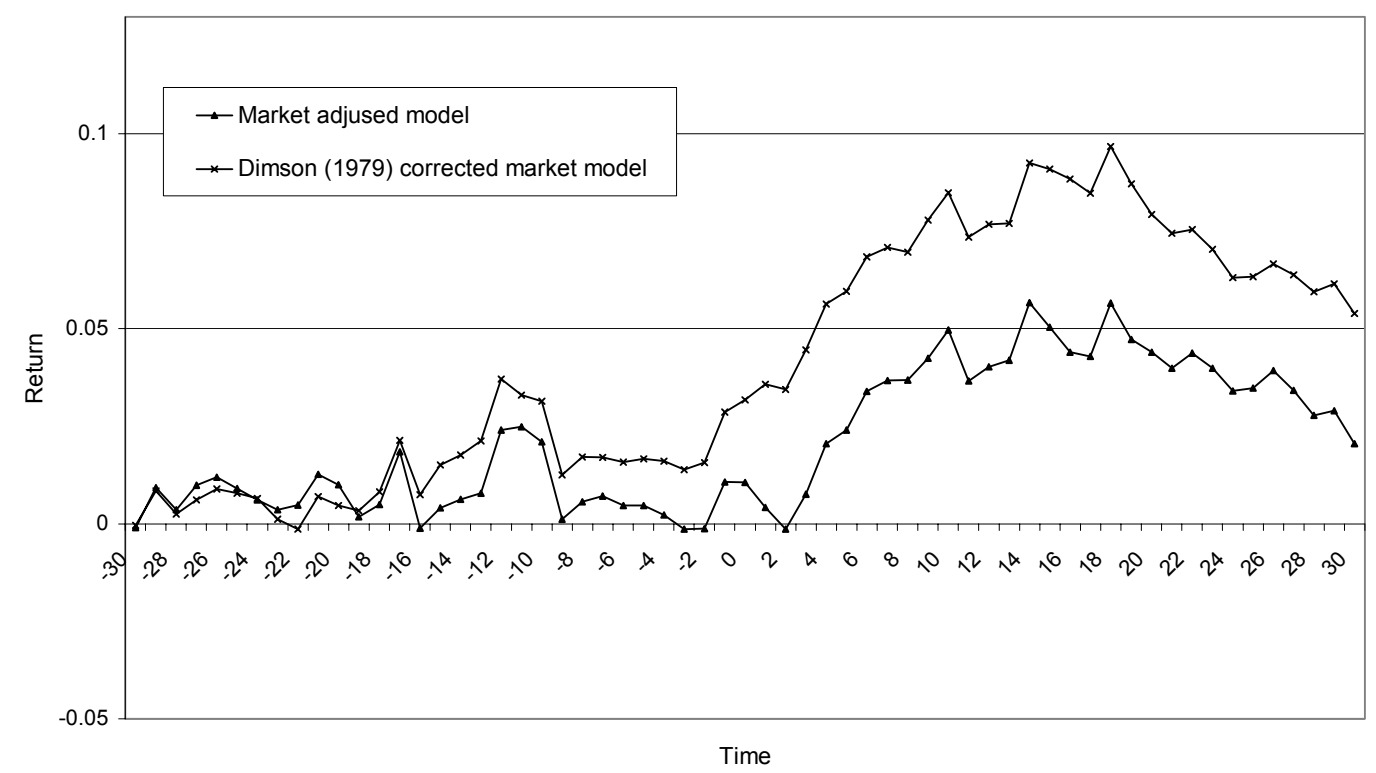

Figure 5: Intragroup equity sales: cumulative average abnormal return of the upper level companies (10 days)

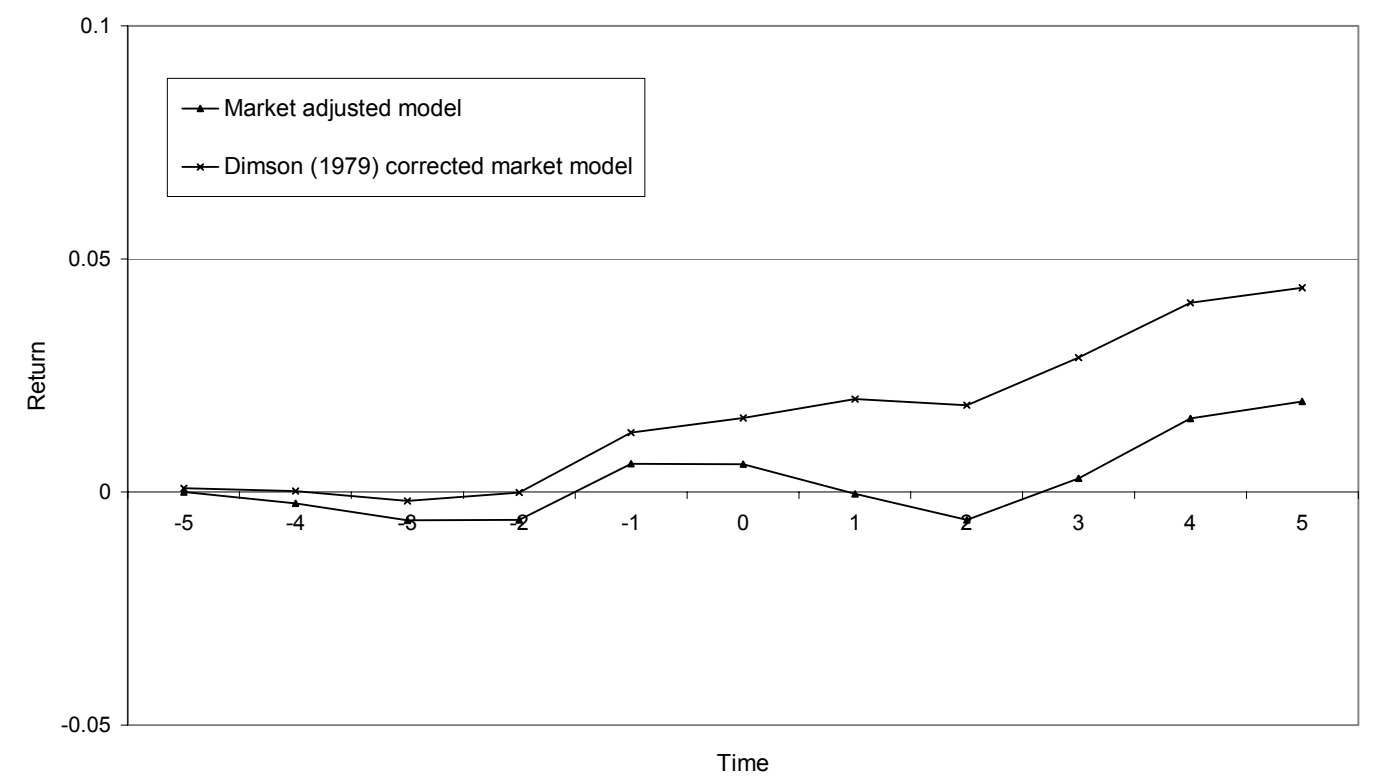


Figure 6: Intragroup equity sales: cumulative average abnormal return of the lower level companies (60 days)

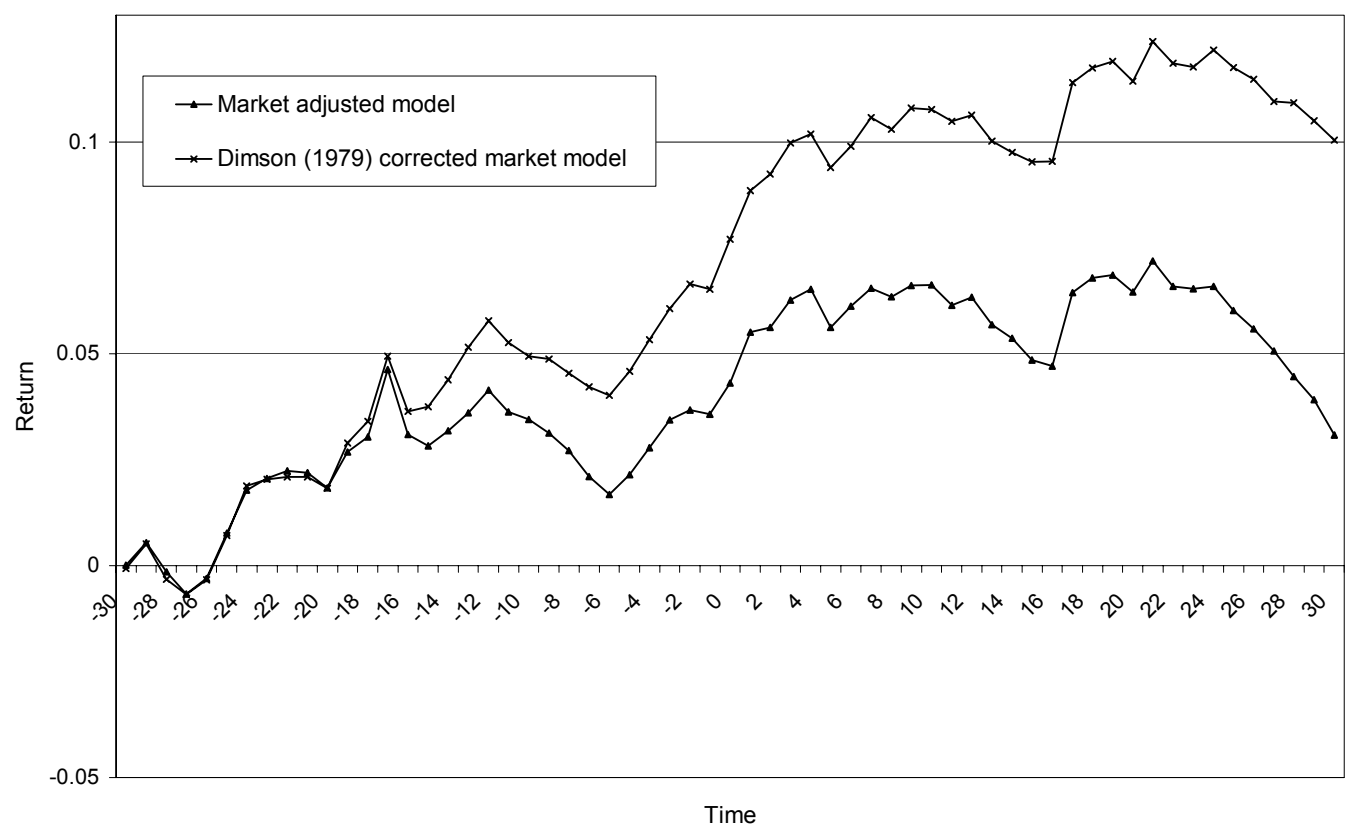

Figure 7: Intragroup equity sales: cumulative average abnormal return of the lower level companies (10 days)

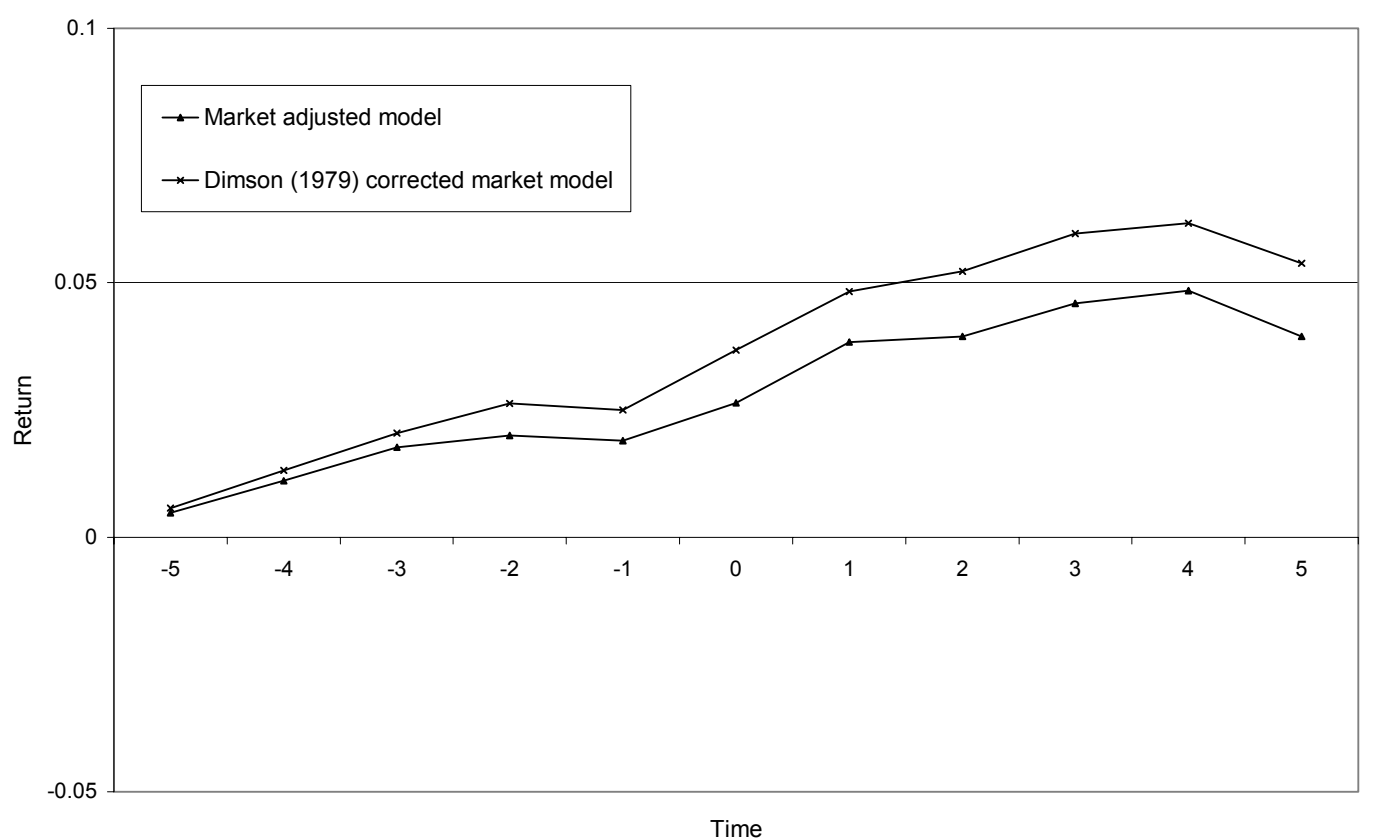


Figure 8: Equity sales involving a listed holding company and a company that does not belong to the same group: cumulative average abnormal return of the holding company (60 days)

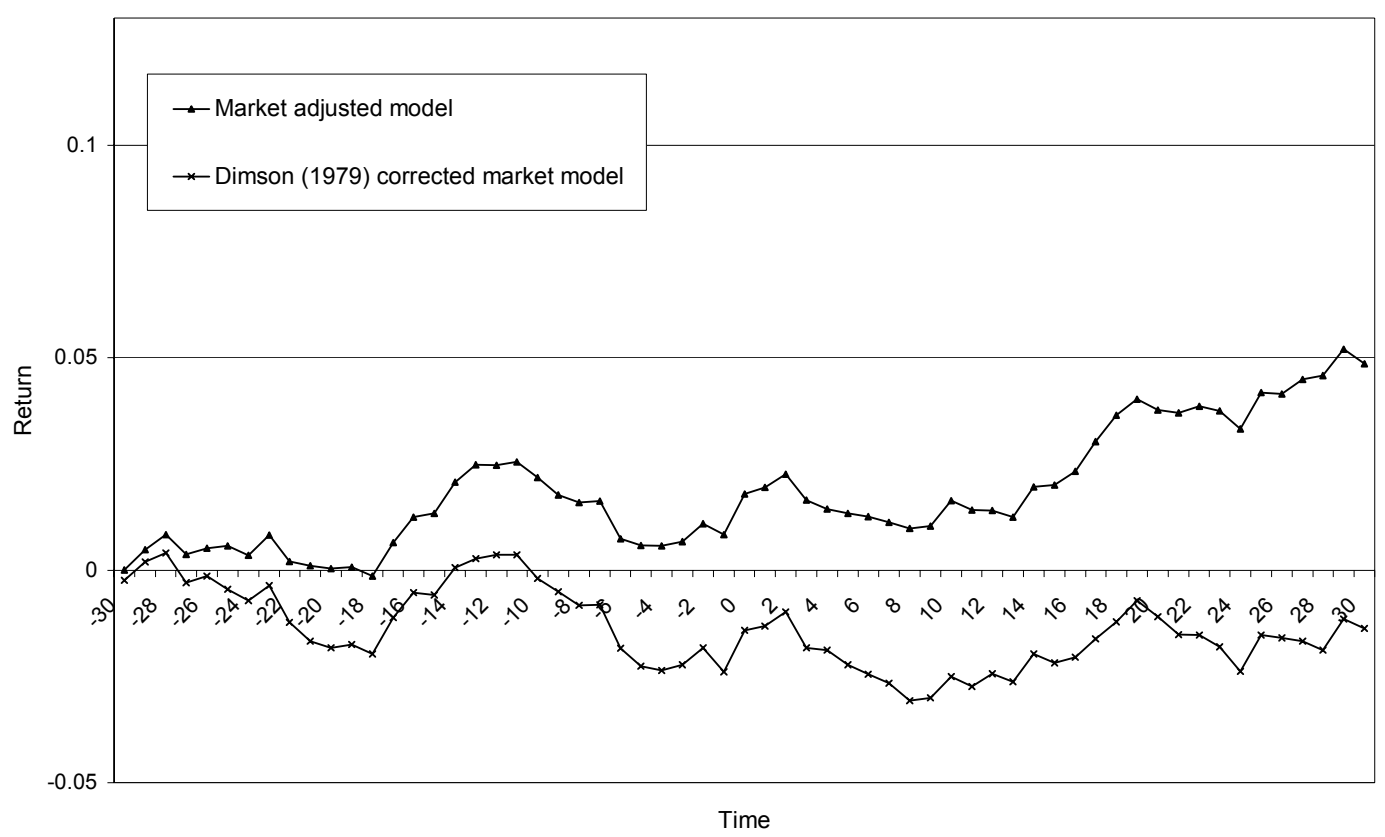

Figure 9: Equity sales involving a listed holding company and a company that does not belong to the same group: cumulative average abnormal return of the holding company (10 days)

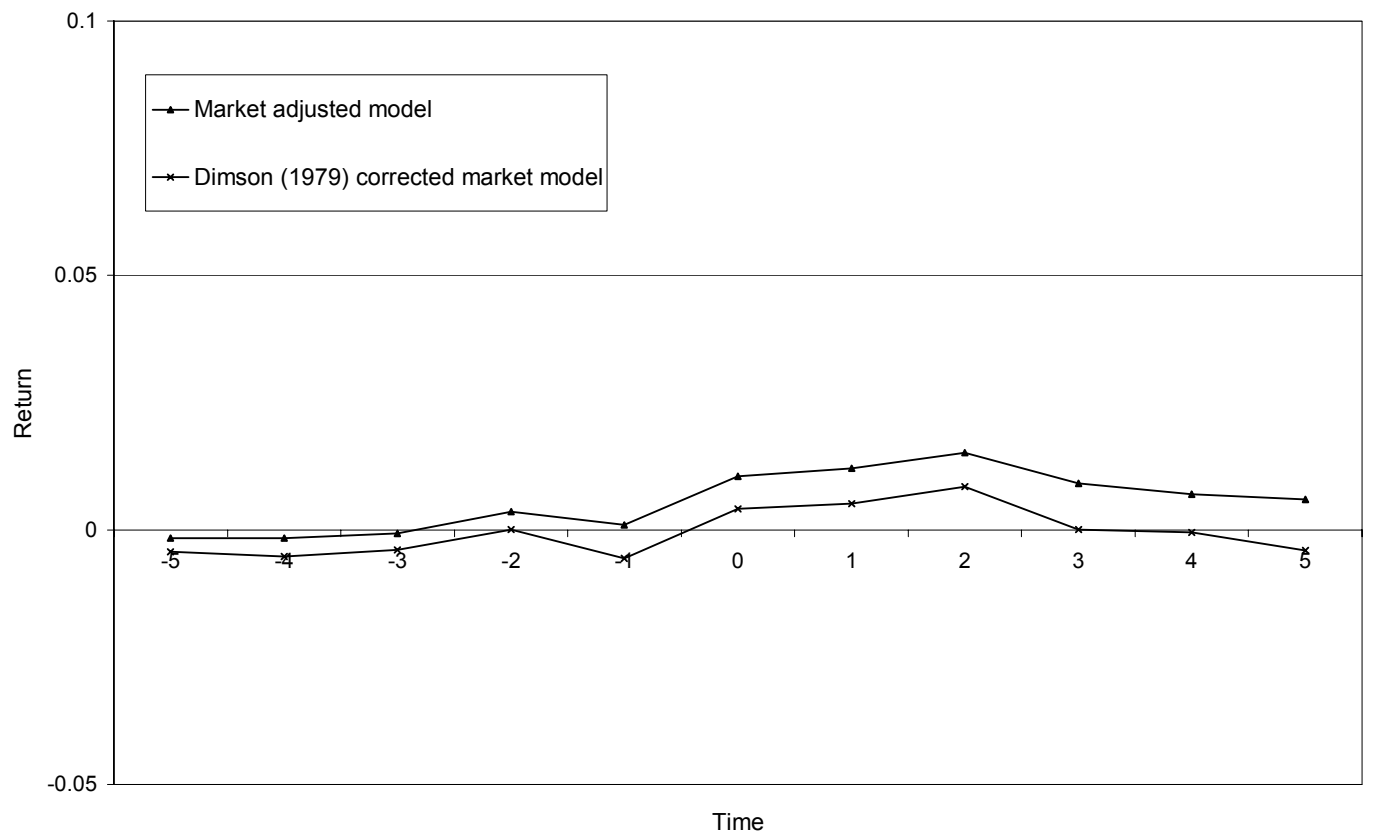


Table 1: Intragroup equity sales involving a listed Belgian holding company (1996-1999)

Note: Panel A and B are not symmetric, because not all companies in Belgian groups are listed on the Belgian Stock Exchange. If these companies are not listed, no return data are available. Belgian holding companies are underlined.

Panel A: Events for which the price reaction of the company located at the upper level will be analyzed (7 events)

\begin{tabular}{c|cccc}
\hline & Upper level & Lower level & Event date & $\begin{array}{c}\text { Traded equity stake of third } \\
\text { company }\end{array}$ \\
\hline $\begin{array}{c}\text { Upper } \\
\text { buys from }\end{array}$ & $\underline{\text { Brederode }}$ & $\underline{\text { Monceau-Zolder }}$ & $12 / 11 / 1999$ & $\begin{array}{c}99.40 \% \text { and } 53 \%(*) \\
\text { NPM }\end{array}$ \\
$\begin{array}{c}\text { Lower } \\
\text { (3 events) }\end{array}$ & $\underline{\text { Henex }}$ & Fafer & $27 / 12 / 1996$ & $9.80 \%$ \\
\hline Upper & $\underline{\text { Auximines }}$ & $\underline{\text { Monceau-Zolder }}$ & $30 / 06 / 1998$ & \\
sells to & $\underline{\text { Auximines }}$ & La Liève & $27 / 10 / 1999$ & $32.20 \%$ \\
Lower & $\underline{\text { Cobepa }}$ & Power & $28 / 05 / 1996$ & $14.20 \%$ \\
(4 events $)$ & $\underline{\text { GBL }}$ & Electrafina & $03 / 05 / 1996$ & $35 \%$ \\
\hline
\end{tabular}

Note: $\left.{ }^{*}\right)$ Several equity sales concerning different companies were announced on the event date.

Panel B: Events for which the price reaction of the company located at the lower level will be analyzed ( 8 events)

\begin{tabular}{c|cccc}
\hline & Lower level & Upper level & Event date & $\begin{array}{c}\text { Traded equity stake of third } \\
\text { company }\end{array}$ \\
\hline $\begin{array}{c}\text { Lower } \\
\text { sells to }\end{array}$ & $\underline{\text { Electrafina }}$ & Frère-Bourgeois & $03 / 04 / 1998$ & $12.70 \%$ \\
Upper & $\underline{\text { GBL }}$ & $\underline{\text { NPM }}$ & $04 / 11 / 1998$ & $95.20 \%, 100 \%$ and $76 \%\left(^{*}\right)$ \\
(4 events) & $\underline{\text { Nonceau-Zolder }}$ & $\underline{\text { Brederode }}$ & $12 / 11 / 1999$ & $99.40 \%$ and $53 \%\left(^{*}\right)$ \\
\hline Lower & $\underline{\text { Electrafina }}$ & Fibelpar & $04 / 10 / 1996$ & $7.06 \%$ \\
buys from & $\underline{\text { Monceau-Zolder }}$ & $\underline{\text { Guximines }}$ & $03 / 05 / 1996$ & $35 \%$ \\
Upper & $\underline{\text { NPM }}$ & Fibelpar & $11 / 05 / 1998$ & $99 \%$ \\
(4 events) & $\underline{\text { NPM }}$ & Erbe & $04 / 11 / 1998$ & $100 \%$ \\
\hline
\end{tabular}

Note: (*) Several equity sales concerning different companies were announced on the event date. 
Table 2: Equity sales involving a listed Belgian holding company and a company that does not belong to the same group (1996-1999) (26 events)

Note: Belgian holding companies are underlined

\begin{tabular}{|c|c|c|c|c|}
\hline & Holding & Lower level & Event date & Equity stake change \\
\hline $\begin{array}{l}\text { The holding } \\
\text { company }\end{array}$ & $\begin{array}{l}\underline{\text { Ackermans } \underline{\&}} \\
\underline{\text { Van Haaren }}\end{array}$ & Sipef & $28 / 02 / 1997$ & $7.70 \%$ \\
\hline $\begin{array}{c}\text { buys an } \\
\text { additional }\end{array}$ & $\begin{array}{l}\underline{\text { Ackermans }} \underline{\&} \\
\underline{\text { Van Haaren }}\end{array}$ & Sipef & 06/05/1997 & $7.50 \%$ \\
\hline equity stake & $\underline{\text { Auximines }}$ & La Liève & $23 / 05 / 1996$ & $37 \%$ \\
\hline in a lower & $\underline{\text { Auximines }}$ & La Liève & 05/07/1996 & $39.80 \%$ \\
\hline level & $\underline{\text { Auximines }}$ & Belgo-Katanga & $11 / 12 / 1996$ & $5.84 \%$ \\
\hline company & $\underline{\text { Bois }} \underline{\text { Sauvage }}$ & Neuhaus & $02 / 12 / 1998$ & $5 \%$ \\
\hline \multirow[t]{9}{*}{ (15 events) } & $\underline{\text { Bois }} \underline{\text { Sauvage }}$ & Neuhaus & $30 / 04 / 1999$ & $5 \%$ \\
\hline & Bois $\underline{\text { Sauvage }}$ & Finpro & $28 / 05 / 1999$ & $82 \%$ \\
\hline & $\underline{\text { Electrafina }}$ & Audiofina & $25 / 04 / 1996$ & $17.20 \%$ \\
\hline & $\underline{\text { Electrafina }}$ & Companie de Suez & $18 / 04 / 1997$ & $6 \%$ \\
\hline & $\underline{\text { GBL }}$ & Electrafina & 05/06/1998 & $24.40 \%$ \\
\hline & $\underline{\text { GBL }}$ & Audiofina & $25 / 11 / 1999$ & $18.70 \%$ \\
\hline & $\underline{\text { Gevaert }}$ & IVG & $06 / 12 / 1996$ & $5.50 \%$ \\
\hline & $\underline{\text { Gevaert }}$ & Holzmann & $13 / 01 / 1999$ & $5.80 \%$ \\
\hline & $\underline{\text { Gevaert }}$ & Afga-Gevaert & $30 / 06 / 1999$ & $5 \%$ \\
\hline $\begin{array}{l}\text { The holding } \\
\text { company }\end{array}$ & $\begin{array}{l}\underline{\text { Ackermans }} \underline{\&} \\
\text { Van Haaren }\end{array}$ & In Touch & $19 / 08 / 1999$ & $50 \%$ \\
\hline sells an & $\underline{\text { Almanij }}$ & Krefima & $30 / 04 / 1997$ & $51 \%$ \\
\hline equity stake & $\underline{\text { Cobepa }}$ & AGJ & 19/11/1996 & $33 \%$ \\
\hline of lower & $\underline{\text { Cobepa }}$ & Paribas België & $26 / 05 / 1997$ & $14.10 \%$ \\
\hline level & Cobepa & Assubel/AGF & 09/12/1998 & $8.60 \%$ \\
\hline company & Deficom & Ring Ring & 05/01/1996 & $51 \%$ \\
\hline \multirow[t]{6}{*}{ (11 events) } & & Companie & & \\
\hline & $\underline{\text { Gevaert }}$ & Hapag-Lloyd & 03/09/1997 & $18 \%$ \\
\hline & $\underline{\text { Gevaert }}$ & Planetinternet & 26/11/1998 & $50 \%$ \\
\hline & $\underline{\text { Gevaert }}$ & IVG & 20/01/1999 & $14.90 \%$ \\
\hline & $\underline{\text { Ibel }}$ & CWA & $24 / 12 / 1998$ & $33 \%$ \\
\hline & $\underline{\text { Sofina }}$ & $\mathrm{SCI}$ & $25 / 03 / 1998$ & $63.80 \%$ \\
\hline
\end{tabular}


Table 3: Average abnormal returns on the announcement date $\left(A A R_{0}\right)$, average cumulative abnormal returns in the 60 days around the announcement date $\left(C A A R_{-30,+30}\right)$, average cumulative abnormal returns in the $\mathbf{1 0}$ days around the announcement date $\left(C A A R_{-5,+5}\right)$ and average rank over 10 days around the annoucement date $\left(\overline{K_{11}}\right)$

\begin{tabular}{|c|c|c|c|c|c|c|c|c|c|}
\hline & \multirow{2}{*}{$\begin{array}{l}\text { Number } \\
\text { of events }\end{array}$} & \multicolumn{4}{|c|}{ Market-Adjusted model } & \multicolumn{4}{|c|}{ Corrected Market model (Dimson, 1979) } \\
\hline & & $A A R_{0}$ & $C A A R_{-30,+30}$ & $C A A R_{-5,+5}$ & $\overline{K_{11}}$ & $A A R_{0}$ & $C A A R_{-30,+30}$ & $C A A R_{-5,+5}$ & $\overline{K_{11}}$ \\
\hline \multicolumn{10}{|c|}{ Intragroup equity sales involving a listed holding company } \\
\hline Price reaction upper level company & 7 & $-9.89 \mathrm{E}-05$ & 0.021 & 0.019 & 86.6 & 0.003 & 0.054 & $0.044^{* *}$ & 88.3 \\
\hline Purchase & 3 & 0.007 & 0.060 & $0.072^{* *}$ & $95.0^{*}$ & 0.014 & 0.083 & $0.072^{* *}$ & $98.1^{* *}$ \\
\hline Sale & 4 & -0.005 & -0.009 & -0.020 & 80.3 & -0.005 & -0.007 & 0.059 & 81.0 \\
\hline Price reaction lower level company & 8 & 0.007 & 0.031 & $0.039^{\text {** }}$ & $94.8^{* * *}$ & $0.012^{* *}$ & $0.100^{* * * *}$ & $0.054^{* * *}$ & $94.8^{* * *}$ \\
\hline Purchase & 4 & 0.008 & 0.017 & $0.059^{* *}$ & $100.6^{* * *}$ & 0.011 & 0.073 & $0.066^{* * *}$ & $99.2^{* * *}$ \\
\hline Sale & 4 & 0.006 & 0.045 & 0.019 & 88.9 & $0.013^{* *}$ & $0.128^{* *}$ & $0.041^{*}$ & 90.5 \\
\hline \multicolumn{10}{|c|}{ Equity sales involving a listed holding company and a company that does not belong to the same group } \\
\hline Price reaction holding company & 26 & 0.009 & 0.048 & 0.006 & 79.5 & $0.009^{* * *}$ & -0.014 & -0.004 & 79.1 \\
\hline Purchase & 15 & 0.009 & 0.067 & 0.018 & 82.1 & $0.008^{* *}$ & -0.008 & 0.002 & 80.1 \\
\hline Sale & 11 & 0.008 & 0.014 & -0.013 & 77.0 & $0.019^{* *}$ & -0.012 & -0.012 & 78.1 \\
\hline
\end{tabular}

Note: significance levels: $\left({ }^{* * *}\right)$ at the $1 \%$ level. $(* *)$ at the $5 \%$ level and $(*)$ at the $10 \%$ level 